DOI: $10.15290 /$ pnib.2020.10

ks. Józef Zabielski

\title{
Arcybiskup Edward Ozorowski - pasterz i teolog
}

Wartościowanie osoby ludzkiej sytuuje się w wyjątkowości i niepowtarzalności jej egzystencji, w tym, co człowiek pozostawia po sobie jako niezapomniany ślad. Już istnienie człowieka ma wyjątkowe aksjologiczne znaczenie, co wyrażają słowa św. Ireneusza Homo vivens, gloria Dei. Uświadomienie tej prawdy zobowiązuje człowieka do takiego życia, żeby swym postępowaniem tę chwałę Boga pomnażać. Tak też na nasze życie patrzy Bóg, „,który odda każdemu według uczynków jego" (Rz 2,7). Takie wartościowanie swej egzystencji świadczy o mądrości danej osoby, dając jej wiele satysfakcji, gdyż: „Lepsze jest dobre imię, niż wonne olejki" (Koh 7,1). Nasza szlachetność nie zatrzymuje się na nas samych oraz szybko się nie wyczerpuje i przedłuża się w czasie, gdyż to co nowe, nakłada się na nasze dokonania i je pogłębia ${ }^{1}$. Stąd też: „Mądry uzyska chwałę u swego narodu, a imię jego żyć będzie na wieki" (Syr 37,26).

Odnosząc ten sposób aksjologicznego postrzegania ludzkiej egzystencji do osoby i dzieła życia abp. Edwarda Ozorowskiego na pierwszy plan wysuwają się dwa wymiary dzieła jego życia: posługa biskupa jako pasterza oraz działalność naukowa jako teologa. W tych dwóch wymiarach pozostał w pamięci osób spotkanych na swej życiowej drodze oraz tych, którzy słuchali jego wykładów i konferencji oraz czytali jego prace. W roku 2019 abp prof. Edward Ozorowski świętuje jubileusz 40-lecia swojej posługi biskupiej i 55-lecia kapłaństwa, co upoważnia i zobowiązuje do przypomnienia dzieła jego życia. W tej analitycznej refleksji jego życiowych dokonań skoncentrujemy się na tych dwóch wymiarach: posłudze pasterskiej oraz pracy naukowej jako teologa.

\section{Arcybiskup Edward Ozorowski jako pasterz Archidiecezji Białostockiej}

Początek posługi duszpasterskiej abp. E. Ozorowskiego datuje się na rok 1964, kiedy przyjął święcenia kapłańskie. Po przyjęciu święceń nie został jednak skierowany do pracy duszpasterskiej, lecz wysłany na studia teologii dogmatycznej na Katolicki Uniwersytet Lubelski w Lublinie. W ramach studiów udzielał się $\mathrm{w}$ posłudze duszpasterskiej $\mathrm{w}$ środowisku akademickim oraz wspomagając wspólnoty parafialne. Kolejnym etapem duszpasterskiej służby była praca

Por. M. C. D. Arcy, The sense of History secular and Sacred, London 1959, s. 274-275. 
nauczyciela akademickiego. Po uzyskaniu doktoratu na KUL-u, w roku 1970 ks. E. Ozorowski został zatrudniony na Wydziale Teologicznym w Akademii Teologii Katolickiej w Warszawie (obecnie Uniwersytet Kardynała Stefana Wyszyńskiego). Posługę duszpasterską realizuje tu jako nauczyciel i wychowawca młodzieży akademickiej. Jego pasterska troska wyraża się w sposobie i formie prowadzonych zajęć, ukazując poszanowanie i wartościowanie słuchaczy. Ksiądz S. Piotrowski, bardzo dobrze znający ks. E. Ozorowskiego podkreśla, że

wykłada jasno i precyzyjnie, pozwala mu na to logiczne myślenie, a w pisaniu znajomość metodologii, w której jest mistrzem. Słowa wypowiedziane są odbiciem jego wiary. Staje na katedrze (mimo wielkości) jako skromny sługa prawdy objawionej, zakotwiczonej w doczesności naznaczonej pieczęcią Bożą. Obca mu jest teologia schematyczna, stąd stale poszukuje, by prawdy Boże przybliżyć współczesnemu człowiekowi. W swych wykładach jest „świeży”, oryginalny, daleki od schematów książkowych. Umie zainteresować wykładaną problematyką tak filozoficzną, jak i teologiczną. Wciąga swoich słuchaczy do dyskusji, zmusza do myślenia, a nie do mechanicznego wkuwania. (...) Optyka jego wykładów uwzględnia słuchacza, jego zainteresowania, trudności, wątpliwości².

Zamiana posługi duszpasterskiej ks. Edwarda Ozorowskiego nastąpiła w roku 1979, kiedy został mianowany przez Papieża Jana Pawła II biskupem tytularnym Bitetto i pomocniczym w Białymstoku. Biskup Ordynariusz białostocki powołał go na rektora Wyższego Seminarium Duchownego w Białymstoku, którym był do 1992 roku. Szczególnym wyzwaniem duszpasterskim jako rektora było zorganizowanie budowy nowego gmachu tego Seminarium. Dotychczas bowiem społeczność seminaryjna korzystała z kilku wynajmowanych pomieszczeń na terenie Białegostoku. Zadaniem duszpasterskim bp. E. Ozorowskiego był też pełniony przez niego urząd wikariusza generalnego Archidiecezji w Białymstoku. Te obowiązki duszpastersko-administracyjne mobilizowały do podejmowania licznych wysiłków, aby zapewnić poprawne funkcjonowanie poszczególnych społeczności diecezji, w tym Seminarium Duchownego. Fundamentalnym zobowiązaniem wobec Seminarium było wybudowanie nowego gmachu tej uczelni. Było to zadanie bardzo trudne i skomplikowane. Najpierw trzeba było zdobyć pozwolenie od władzy państwowej na tę budowę. Nie było to łatwe w ówczesnym systemie politycznym. Starania trwały sporo czasu, ale skończyły się pozytywnie. Kolejnym wyzwaniem było znalezienie miejsca na budowę tego obiektu. Tutaj też nie było łatwo; wskazywano kilka miejsc, ale nie wszystkie były do przyjęcia. Wreszcie zdecydowano się na budowę obiektu seminaryjnego przy ul. Warszawskiej 46, gdzie obecnie się znajduje. Trzeba było też zdobyć odpowiednie fundusze, co również sprawiało dużo wyzwań, ale też zostały przezwyciężone. Ksiądz bp E. Ozorowski jako rektor spełnił dzielnie swe zadanie i Kościół białostocki może dzisiaj cieszyć się dobrym miejscem i budynkiem seminaryjnym. Jako rektor zaangażował się też w organizację życia

S. Piotrowski, Uczeń, który stał się mistrzem, [w:] „W Tym, Który umacnia”, red. J. Zabielski, Białystok 2004, s. 61. 
seminaryjnego w wymiarze edukacyjno-wychowawczym. Trzeba było skompletować i odpowiednią kadrę wykładowców Seminarium, co również sprawiało wiele problemów, gdyż nie było odpowiednich osób spełniających wymogi pod względem wykształcenia i przygotowania pedagogicznego. Z tym zadaniem bp E. Ozorowski zmagał się długi czas, ale jakoś to pokonał’

Powołanie biskupie poszerzyło obowiązki i możliwości duszpasterskie bp. E. Ozorowskiego. Jego zaangażowanie pasterskie wykraczało poza granice diecezji w Białymstoku. Jako biskup zostaje włączany w szereg organizacji i społeczności ogólnopolskich i zagranicznych. W tym czasie jest członkiem: Komisji Nauki Wiary Episkopatu Polski; Komisji Kultu i Dyscypliny Sakramentów Konferencji Episkopatu Polski; Zespołu KEP do spraw Sanktuariów w Polsce; Polskiego Towarzystwa Mariologicznego; International Biographical Centre, American Biographical Institute (ABI), Geographical Society ${ }^{4}$.

Wyzwaniem duszpasterskim bp. E. Ozorowskiego było przygotowanie wizyty Papieża Jana Pawła II w Białymstoku w roku 1991. Jako biskup pomocniczy - najbliższy współpracownik ordynariusza bp. E. Kisiela był zaangażowany we wszelkie formy przygotowań do tej pierwszej papieskiej wizyty w Archidiecezji w Białymstoku. Z tą wizytą wiązano oczekiwania na wiele zmian nie tylko w Kościele białostockim, ale w całej Polsce. Spodziewano się zmian administracyjnych w polskim Kościele, co Papież Jan Paweł II ogłosił w tym czasie. Podczas Mszy św. sprawowanej w Białymstoku Papież ogłosił ustanowienie Archidiecezji Białostockiej oraz beatyfikację bł. Bolesławy Lament. Fakty te zobowiązywały do duszpasterskiej organizacji ustanowionej Archidiecezji Białostockiej oraz całej metropolii, do której włączone zostały diecezje drohiczyńska i łomżyńska. Przed papieską wizytą bp E. Ozorowski bardzo aktywnie zaangażował się w przygotowania do tego szczególnego wydarzenia, zarówno pod względem organizacji zewnętrznej, ale szczególnie w formację religijno-moralną. Jego wysiłki duszpasterskie odniosły swój pozytywny skutek. We Mszy św. sprawowanej przez Jan Pawła II uczestniczyło bardzo wielu ludzi, nie tylko z Polski, ale też z sąsiednich krajów, zwłaszcza ze Wschodu - Litwy, Białorusi, Ukrainy. Papież odwiedził także Wyższe Seminarium Duchowne w Białymstoku, co również wymagało szczególnego zaangażowania bp. E. Ozorowskiego jako rektora tej uczelni. Radosne wspomnienia wizyty Jana Pawła II pozostają do dzisiaj w pamięci wielu osób z naszej Archidiecezji, co też potwierdza skuteczność duszpasterskich wysiłków bp. E. Ozorowskiego ${ }^{5}$.

Por. Cz. Rychlicki, Arcybiskup Edward Ozorowski w dialogu teologii i Magisterium Kościoła, „Rocznik Teologii Katolickiej", 2014, t. III/I, s. 9-10.

$4 \quad$ Zob. Ibidem, s. 11. Por. J. Salij, "Kto dąży do biskupstwa, dobrego zadania pragnie” $(1 T$ m 3,1) w interpretacji świętego Tomasza z Akwinu, [w:] „W Tym, Który umacnia”, red. J. Zabielski, Białystok 2004, s. 81-87.

$5 \quad$ Por. J. Zabielski, Przed wizytą. Archidiecezja w Białymstoku, Białystok 1991; Idem, Zagrożenia moralne Archidiecezji w Białymstoku i sposoby zaradzenia im, „Wiadomości Kościelne Archidiecezji Białostockiej”, 1(1992), nr 3, s. 49-53. 
Szczególne wyzwanie duszpasterskie spotkało abp. E. Ozorowskiego dnia 21 października 2006 roku, kiedy to papież Benedykt XVI mianował go Arcybiskupem Metropolitą Białostockim. Przejęcie duchowo-administracyjnej władzy nad całą społecznością białostockiego Kościoła powiązane było z szerokim spectrum zobowiązań. Jako Arcybiskup Metropolita był odpowiedzialny za całą społeczność tego Kościoła. Do niego należały decyzje administracyjne, personalna obsada stanowisk osób duchownych, organizacja działalności katechetyczno-wychowawczej, życie duchowo-moralne Archidiecezji i szereg innych wyzwań, które przynosił każdy dzień. Wyzwaniu temu abp E. Ozorowski sprostał w stopniu bardzo dobrym. Potwierdzeniem tego jest fakt, że za jego rządów w Archidiecezji Białostockiej nie było żadnych dramatycznych wydarzenia, oprócz drobnych, co jest znakiem zwykłej ludzkiej słabości. Ta stabilność egzystencji białostockiego Kościoła potwierdza poprawne ukierunkowanie zarządzania Archidiecezją Białostocką przez abp. E. Ozorowskiego. Jeszcze bardziej potwierdza to rozwój życia religijnego tego Kościoła: powstawanie wielu nowych społeczności religijnych, organizowanie życia katechetyczno-duchowego, rozwój aktywności społeczno-religijnej. Jako pasterz Archidiecezji Białostockiej abp E. Ozorowski musiał też zmierzyć się z aktualnymi wyzwaniami religijno-moralnymi, czego przykładem może być sztuczne poczęcie człowieka - in vitro, które w Polsce zostało pierwszy raz dokonane w Białymstoku. Jako pasterz zobowiązany był wielokrotnie stawać przed podobnymi wyzwaniami, z których wychodził zwycięsko, poprawnie je interpretując i czytelnie uzasadniając nauczanie Kościoła i jego stanowisko ${ }^{6}$.

\section{Arcybiskup Edward Ozorowski jako teolog}

Zaangażowanie w poznawanie i rozwój teologii stanowi drugie „powołanie” abp. E. Ozorowskiego. Początkiem jego spotkania z teologią były studia w Seminarium Duchownym w Białymstoku. Po studiach seminaryjnych i przyjęciu sakramentu kapłaństwa został skierowany na studia specjalistyczne z teologii dogmatycznej w Katolickim Uniwersytecie Lubelskim. W ramach tych studiów w roku 1967 uzyskał tytuł magistra teologii, w roku 1970 stopień naukowy doktora nauk teologicznych na podstawie rozprawy Nauka wspótczesnych teologów katolickich o kulcie Świętych w życiu Kościoła pielgrzymującego - od Mystici Corporis do Vaticanum II. Stopień naukowy doktora habilitowanego uzyskał w roku 1976 na podstawie dorobku naukowego i rozprawy Eklezjologia unicka w latach 1596-1720. Pracę na uczelni wyższej rozpoczął w roku 1970 na Wydziale Teologicznym w Akademii Teologii Katolickiej (obecnie UKSW) w Warszawie.

Por. J. Zabielski, Inspirująca rola katolików świeckich w budowaniu odpowiedzialnych struktur życia społecznego, „Rocznik Teologii Katolickiej Uniwersytetu w Białymstoku”, 5(2006), s. 131-143; Idem, Etyczne podstawy małżeństwa, [w:] Małżeństwo - etyka - ekonomia, red. E. Ozorowski, R. Cz. Horodeński, Białystok 2007, s. 17-31. 
W ramach tej pracy uzyskuje kolejne awanse naukowo-badawcze: w roku 1978 stopień naukowy docenta, w roku 1987 tytuł naukowy profesora nadany przez Radę Państwa, w roku 1995 stanowisko profesora zwyczajnego ATK (UKSW). Za aktywną działalność naukową w roku 1991 otrzymał nagrodę indywidualną MEN, w roku 1992 złoty medal Research Fellow ABI, w oku 2002 Nagrodę im. W. Pietrzaka nadaną przez „Civitas Christiana”. Jako zaangażowany teolog w latach 1970- 1979 pełnił funkcję sekretarza naukowego czasopisma „Studia Theologica Varsaviensia”, zaś w latach 1983-1992 był redaktorem „Studiów Teologicznych: Białostocko-Drohiczyńsko-Łomżyńskich” oraz współredaktorem „Słownika Teologów Katolickich” (tom I-IV). Był też organizatorem i czynnym uczestnikiem licznych sympozjów, konferencji i kongresów naukowych w Polsce i za granicą: Rzym - 1989; Rimini - 1991; Edmonton - 1992; Jerozolima 1994; La Thuil - 19947.

Działalność naukowo-badawcza wyraża się też w pracy dydaktycznej. W tym zakresie abp prof. E. Ozorowski ma też liczne dokonania i zasługi. Jest promotorem trzech rozpraw doktorskich. W zaangażowaniu promotora kierował pracą doktorantów, przekazując im zasady metodologiczne badań naukowych, ucząc analiz bazy źródłowej i wyciągania merytorycznie zasadnych wniosków. Jako doświadczony teolog wielokrotnie był też powoływany na recenzenta rozpraw doktorskich, habilitacyjnych i tytułów naukowych profesora; w sumie przygotował 29 tego rodzaju recenzji. Szczególnym wyrazem docenienia jego dojrzałości naukowej jako teologa i dydaktyka było trzykrotne powołanie go na promotora doktoratów honoris causa. Tak liczne powołania na promotora i recenzenta stanowią potwierdzenie wysokiej klasy dorobku naukowo-badawczego, co przekłada się na rozpoznawanie abp prof. E. Ozorowskiego jako dojrzałego teologa ${ }^{8}$.

Szczególnym wyrazem działalności naukowo-badawczej każdego naukowca są publikacje. Dorobek naukowy abp. prof. E. Ozorowskiego jest imponujący. Jest autorem około 1300 pozycji, w tym około 30 są to publikacje książkowe. Oprócz książek opublikował artykuły naukowo- badawcze i popularyzatorskie, recenzje książek, bardzo liczne hasła z zakresu nauk teologicznych, hasła osobowe, przemówienia, odezwy administracyjne, listy pasterskie. Problematyką jego badań jest przede wszystkim eklezjologia i tematyka z nią powiązana, czyli chrystologia, mariologia, nauka o sakramentach oraz teologia małżeństwa i rodziny. Zagadnienia te abp E. Ozorowski ukazuje zarówno w wymiarze ściśle teologiczno-naukowym oraz duszpastersko-formacyjnym. Lektura jego publikacji poświadcza, że Autor ukazuje Kościół jako ustanowiony przez Boga „środek" do realizacji Jego zbawczego planu wobec człowieka i świata9.

Zob. Cz. Rychlicki, Arcybiskup Edward Ozorowski w dialogu teologii z Magisterium Kościoła, s. 10-11.

8 Zob. M. Ozorowski, Wykaz publikacji ks. abpa prof. Edwarda Ozorowskiego, „Studia Theologica Varsaviensia", 45(2007), nr 1, s. 123-124.

9 Zob. idem, Kościół. Zarys eklezjologii katolickiej, Wrocław 1984. 
W analizach zbawczego działania Kościoła abp prof. E. Ozorowski podkreśla rolę Słowa Bożego i sakramentów, wśród których szczególne miejsce zajmuje Eucharystia. Jest to bowiem źródło życia nadprzyrodzonego, „ziarno”, które poprzez realizację wezwania Stwórcy, prowadzi człowieka do zbawczego celu. Przykładem realizacji tej rzeczywistości jest życie świętych. To jest kolejny temat, którym zajmuje się nasz Autor. Zainteresowanie kultem świętych, zwłaszcza męczenników przez abp. prof. E. Ozorowskiego było motywowane potrzebami badawczym, ale też osobistymi i duszpasterskimi. Pragnął on utrwalić w życiu chrześcijan pamięć o męczennikach w historii Polski i całego Kościoła. Kolejnym motywem naszego Teologa do analitycznego pochylania się nad życiem świętych były uwarunkowania lokalne. W Kościele białostockim szczególnie aktualna jest problematyka Bożego Miłosierdzia. Powiązane jest to z ks. Michałem Sopoćko oraz s. Faustyną Kowalską, którzy stanowią "teologiczne symbole" tego kultu. Podejmowanie tej problematyki przez abp. E. Ozorowskiego jako pasterza tego Kościoła lokalnego jest wyrazem jego wrażliwości na znaki czasu związane z tym miejscem ${ }^{10}$.

Teologiczne zaangażowanie abp. prof. E. Ozorowskiego w rozwijanie kultu Bożego Miłosierdzia oraz eksponowanie roli s. Faustyny i ks. M. Sopocki jest wyrazem wdzięcznej pamięci oraz odpowiedzialności teologa i biskupa za zachowanie tego skarbca ludzi i religijnej kultury Kościoła. Wyrazem szacunku i wrażliwości tego Teologa jest zaangażowanie w odkrywanie natury Boga, co zawarte jest w książce Bóg jest Miłością. Misterium Ojcostwa Boga ${ }^{11}$. Zagadnienia teologiczne tej książki skupione są na aktualnej sytuacji chrześcijanina podejmującego swe decyzje życiowe „w imię Ojca”, wyrażając swą wiarę w Boga jako źródło i cel swej ziemskiej egzystencji. Problematyka ta jest bardzo dzisiaj ważna, kiedy szerzą się zagrożenia w rozumieniu religijnej wiary oraz jej życiowej praktyki. Mając to na względzie abp prof. E. Ozorowski stara się ukazać prawdziwe oblicze Boga nie ograniczając się tylko do twierdzeń teologicznych, ale wyjaśnia ojcowskie oblicze Boga. Podkreśla stosunek Boga do ludzkiego cierpienia i wszelkich zagrożeń ludzkiej egzystencji ${ }^{12}$.

Teologiczne analizy tych zagadnień prowadzą abp. prof. E. Ozorowskiego do wniosku, że chrześcijańska wiara opiera się na Osobie i zbawczym dziele Jezusa Chrystusa ukazującym „ojcowskie” oblicze Boga (por. J 14, 9-12). W swoich teologicznych analizach ukazuje on tę myśl jako czytelne przesłanie wiary, co odnosi także do roli Maryi - Matki Jezusa w dziele odkupienia. Macierzyństwo Matki Bożej ma swe przełożenie na godność każdej kobiety oraz ogólne

$10 \quad$ Por. E. Ozorowski, Eucharystia w nauce i praktyce Kościoła katolickiego, Poznań 1990; Idem, Eklezjalne aspekty kultu świętych w nauce wspótczesnych teologów katolickich, "Studia Teologiczno-Dogmatyczne", t. 1, Warszawa 1974, s. 5-135.

11 Zob. idem, Bóg jest Miłością. Misterium Ojcostwa Boga, Białystok 1999.

12 Zob. Cz. Rychlicki, Arcybiskup Edward Ozorowski w dialogu teologii z Magisterium Kościoła, s. 13-14. 
powołanie człowieka na zasadzie równości mężczyzny i kobiety (por. Rdz 1, 2627) ${ }^{13}$. Odniesienie do wzoru kobiecości Maryi jako Matki Jezusa ma swe przełożenie na analizy małżeństwa i rodziny, pojmowanej jako fundamentalna społeczność w kształtowaniu osoby ludzkiej i społeczności. Teologiczne zaangażowanie abp. E. Ozorowskiego w problematykę rodziny i małżeństwa powiązane jest z jego pracą profesora w Instytucie Studiów nad Rodziną (obecnie Wydział Nauk o Rodzinie UKSW). W swych analizach małżeństwa i rodziny podkreśla, że ojcostwa i macierzyństwo są wyrazem miłości małżeńskiej. Współcześnie, w kontekście nie zawsze poprawnie rozumianej wolności i pod wpływem różnych koncepcji kulturowo-politycznych, rozwijają się postawy prywatyzacji małżeństwa oraz religii i wiary. Arcybiskup prof. E. Ozorowski przypomina, że jedynym możliwym do akceptacji przez wierzących ludzi, jest model rodziny oparty na związku mężczyzny i kobiety ${ }^{14}$.

Reasumując analizy bardzo licznego dorobku naukowego abp. prof. E. Ozorowskiego zwróćmy uwagę na jego oryginalność. Dobry znawca tych publikacji oraz samego Autora ks. prof. Cz. Rychlicki stwierdza:

Przede wszystkim jest to teologia oparta na obiektywnych źródłach poznania teologicznego. Znaczący jest teologiczny wkład Biskupa Białegostoku szczególnie w eklezjologię i sakramentologię. Refleksja w tej dziedzinie zdaje się wypływać z osobistej głębokiej wiary naszego Teologa i jego poczucia odpowiedzialności za duchową formację chrześcijanina. Bardzo znaczące miejsce w teologii abp. E. Ozorowskiego zajmuje również kult Świętych i Miłosierdzia Bożego. Mając na uwadze soborowe wypowiedzi na temat kultu Świętych (LG VII) w Kościele katolickim, abp E. Ozorowski przywołuje wskazania Soboru Watykańskiego II, który sankcjonując prawo dla tego kultu przestrzega przed jego nadużyciami, zaznaczając, że pozostaje on zgodny z nauką Kościoła o jedynym pośrednictwie zbawczym Chrystusa, w którym inne formy pośrednictwa są traktowane jako pośrednictwo udziału ${ }^{15}$.

Niniejsze analizy ukazują dwa wymiary życiowego powołania abp. prof. E. Ozorowskiego: kapłaństwo - posługa pasterska i naukowca-teologa. Na tych dwóch płaszczyznach realizował fundamentalne wyzwania swej egzystencji. Skutki tych wysiłków składają się na duchowe przewodnictwo kapłana - biskupa oraz dorobek naukowo - badawczy w piśmiennictwie i wychowaniu nowego pokolenia teologów. W refleksji nad życiowym powołaniem H. Hesse stwierdza:

Istnieje wiele sposobów i rodzajów powołania, sedno jednak i sens tego przeżycia są zawsze jednakie: dusza zostaje przez nie zbudowana, odmieniona, a siły jej wzmożone wskutek tego, iż oto zamiast marzeń i przeczuć wewnętrznych pojawia się nagle zew z zewnątrz, ingeruje w nie fragment rzeczywistości"16.

13 Por. E. Ozorowski, Maryjny rys kobiecości kobiety jako dziewicy, „Studia Teologiczne: Białystok - Drohiczyn - Łomża", nr 13.

14 Por. idem, Małżeństwo i rodzina w zamyśle Bożym, Warszawa 2009; Idem, Małżeństwo jako związek mężczyzny i kobiety, "Studia nad Rodziną”, 8(2004), nr 1.

15 Cz. Rychlicki, Arcybiskup Edward Ozorowski w dialogu teologii z Magisterium Kościoła, s. 15. Por. M. Ozorowski, Wykaz publikacji ks. abpa prof. dra hab. Edwarda Ozorowskiego, s. 123-163.

16 H. Hesse, Gra szklanych paciorków, tłum. M. Kurecka, Poznań 1971, s. 56. 


\section{Bibliografia}

Arcy M. C. D., The sense of History secular and Sacred, London 1959

Hesse H., Gra szklanych paciorków, tłum. M. Kurecka, Poznań 1971.

Ozorowski E., Bóg jest Miłością. Misterium Ojcostwa Boga, Białystok 1999.

Ozorowski E., Eklezjalne aspekty kultu świętych w nauce współczesnych teologów katolickich, „Studia Teologiczno-Dogmatyczne”, t. 1, Warszawa 1974.

Ozorowski E., Eucharystia w nauce i praktyce Kościoła katolickiego, Poznań 1990

Ozorowski E., Kościót. Zarys eklezjologii katolickiej, Wrocław 1984.

Ozorowski E., Maryjny rys kobiecości kobiety jako dziewicy, „Studia Teologiczne: Białystok - Drohiczyn - Łomża", nr 13.

Ozorowski E., Małżeństwo i rodzina w zamyśle Bożym, Warszawa 2009.

Ozorowski E., Małżenstwo jako związek mężczyzny i kobiety, "Studia nad Rodziną", 8(2004), nr 1.

Ozorowski M., Wykaz publikacji ks. abpa prof. Edwarda Ozorowskiego, „Studia Theologica Varsaviensia", 45(2007), nr 1.

Piotrowski S., Uczeń, który stał się mistrzem, [w:] „W Tym, Który umacnia”, red. J. Zabielski, Białystok 2004.

Rychlicki C., Arcybiskup Edward Ozorowski w dialogu teologii i Magisterium Kościoła, „Rocznik Teologii Katolickiej”, 2014, t. III/I.

Salij J., "Kto dąży do biskupstwa, dobrego zadania pragnie” (1Tm 3,1) w interpretacji świętego Tomasza z Akwinu, [w:] „W Tym, Który umacnia”, red. J. Zabielski, Białystok 2004.

Zabielski J., Etyczne podstawy małżeństwa, [w:] Małżeństwo - etyka - ekonomia, red. E. Ozorowski, R. Cz. Horodeński, Białystok 2007.

Zabielski J., Inspirująca rola katolików świeckich w budowaniu odpowiedzialnych struktur życia społecznego, „Rocznik Teologii Katolickiej Uniwersytetu w Białymsto$\mathrm{ku}^{\prime \prime}$, 5(2006).

Zabielski J., Przed wizyta. Archidiecezja w Białymstoku, Białystok 1991.

Zabielski J., Zagrożenia moralne Archidiecezji w Białymstoku i sposoby zaradzenia im, „Wiadomości Kościelne Archidiecezji Białostockiej”, 1(1992), nr 3. 